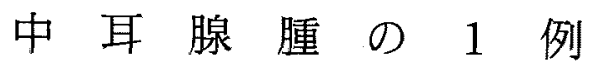 \\ 大阪医科大学耳鼻咽喉科学教室（主任：高橋宏明教授） \\ 林伊吹, 牧本一男, 奥村雅史, 山本祐三, 高橋宏明
}

\section{A CASE OF MIDDLE EAR ADENOMA}

\author{
IBUKI HAYASHI, M.D., KAZUO MAKIMOTO, M.D., MASASHI OKUMURA, M.D. \\ YUZO YAMAMOTO, M.D. and HIROAKI TAKAHASHI, M.D.
}

Department of Otolaryngology, Osaka Medical College, Osaka

\begin{abstract}
Middle ear adenomas are rare and difficult to diagnose. Recent histological studies suggest the presence of a distinct disease entity known as a middle ear adenoma.

A 16-year-old boy with a middle ear tumor was treated by partial temporal bone resection, and the tumor was removed by a combined method using the middle cranial fossa and infratemporal fossa approaches. Histological and immunohistochemical studies on this tumor showed the findings of a benign adenoma. Left facial palsy was noted postoperatively, but it subsequently recovered almost completely.
\end{abstract}

Key words : 中耳, 腺腫, partial resection, S-100 蛋白 A96-2073-22201

はじめに

中耳腺腫は，非常にまれな腫漝で，1898年に Treitel ${ }^{1)}$ にってて初めて記載されて以来, 近年に至る まで文献的にはほとんど報告がなかった。最近著者ら は, 孚突蜂覓の中耳粘膜原発と考えられた腺腫を経験 したので，若干の文献的考察を加えて報告する．

\section{症例}

症例：16歳, 男性, 高校生

主訴：左耳鳴, 左難聴

既往歴：家族歷：特記すべきことなし

現病歴：昭和63年 9 月頃突然左耳鳴, 左難聴に気付 き, 近医で左突発性難聴として治療をうけたが軽快し なかった。その後, 難聴が進行したため, 平成元年 4 月に精查目的で大阪医科大学耳鼻咽喉科に紹介され t.

初猃時所見: 左鼓膜には異常所見を認めなかった。 聴力検査では, 左耳聴力は平均 $87.5 \mathrm{~dB}$ の高度の混合 性難聴を示していた（図1)。単純レ線では, Schüller
法, Stenvers 法とも異常所見は認められなかった。内 耳道断層撮影では, 左内耳道周辺に骨融解像が認めら れた(図 2). 造影 CT でも水平断で左錘体部に骨融解 像を認めた。しかし，C-P angle を含めて頭蓋内には 明瞭な腫瘍病変を示す所見は認められなかった（図 3 ).

ABR では，左側は $70 \mathrm{~dB} \mathrm{nHL}, 80 \mathrm{~dB}$ nHL に対する 反応を全く認めなかった。カロリック㭘査では，左側 は $20^{\circ} \mathrm{C}, 3^{\circ} \mathrm{C}$ の冷水刺激に反応がなかった。顔面神経 検查では，耳小骨筋反射は左耳で同側および対側刺激 で反応を認めなかった，その他の検査は，筋電図を含 めて異常を認めなかった。

MRI を施行したところ, 左側頭骨に $T_{1}$ 強調像で等 ＼cjkstart高信号域, $T_{2}$ 強調像で高信号域の領域が認められ (図 4), 上記の造影 CT の病変に一致する部位と考え られた。

これらの検査により, 潜在性の中耳炎あるいは側頭 骨内の腫湯が疑われた。

入院時所見：その後も難聴が進行し，9月11日の聴 

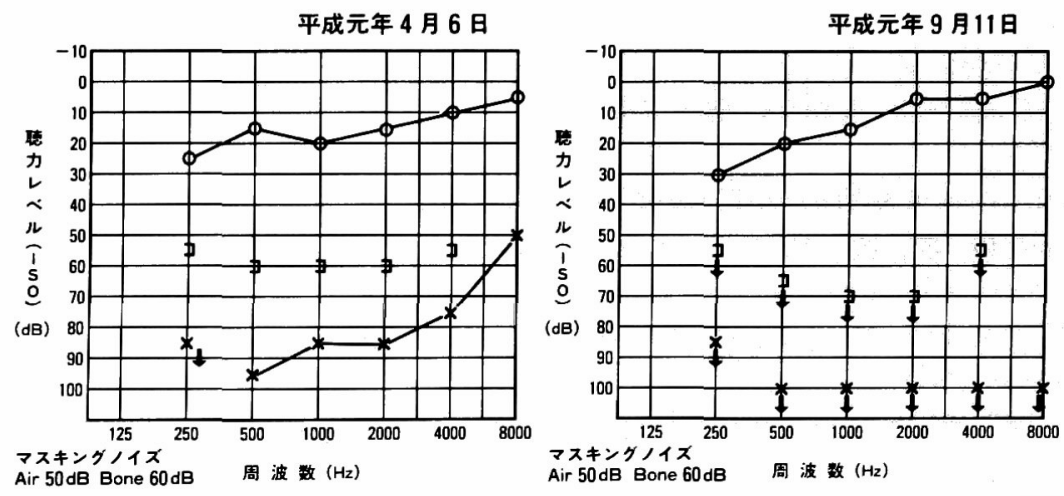

図 1 Audiograms

左は初診時の Audiogram で, 右は入院時のものである.

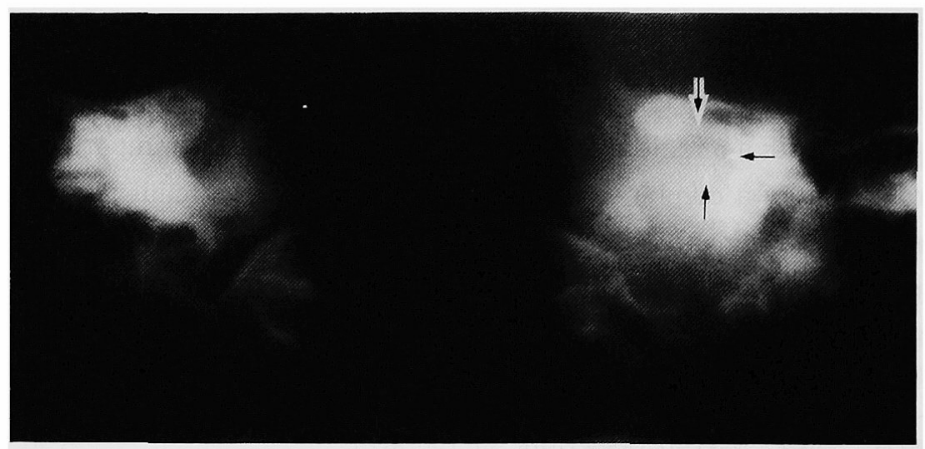

図 2 内耳道断層撮影

左内耳道周囲の矢印で示した部分に骨融解像が認められる.

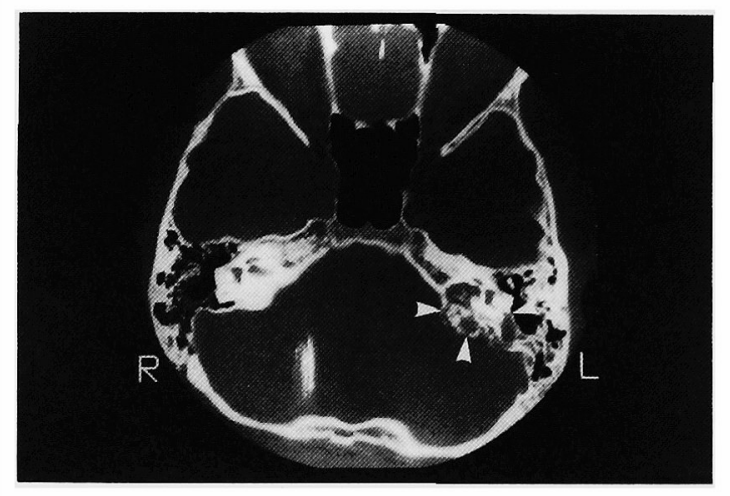

図 3 CT（側頭骨水平断）

矢印で示した部分に骨融解像が認められ る.

力検査では左耳は全暗となった(図 1)。そのため, 10 月11日精査加療のため入院となった。

$\mathrm{Ga}$ シンチ，骨シンチでは集積を認めなかったため, 悪性腫瘍, 骨腫瘍の可能性は低いと考えられた。
CT, MRIによる腫湟の存在部位より, Glomus jugulare tumor, その他側頭骨に発生するカルチノイ ドなどの腫湯を考え, 血中カテコラミン濃度を測定し たが，ほほ正常であり(表 1)，尿中カテコラミン濃度 にも異常はみられなかった(表 2). 左頸静脈造影の際, 左内頸静脈, 大腿静脈より採血し，カテコラミン濃度 を測定したが，これらの腫崵に特徴的とされる，左内 頸静脈の濃度が大服静脈より高值を示すという結果は 得られなかった（表 3 ).

ガドリニウム造影 MRI では, 左側頭骨内の $\mathrm{T}_{2}$ 強調 像の高信号域に一致する部位で，著明に信号が増強さ れた（図 5 )。

また，左頸動脈造影では，上行咽頭動脈よりの腫县 膿染像を認めた (図 6 ).

以上の検查結果より, カテコラミン濃度に有意な所 見はなかったが，側頭骨錘体部に存在する良性腫瘍の 中で, Glomus jugulare tumor の可能性が高いと考え られた。 


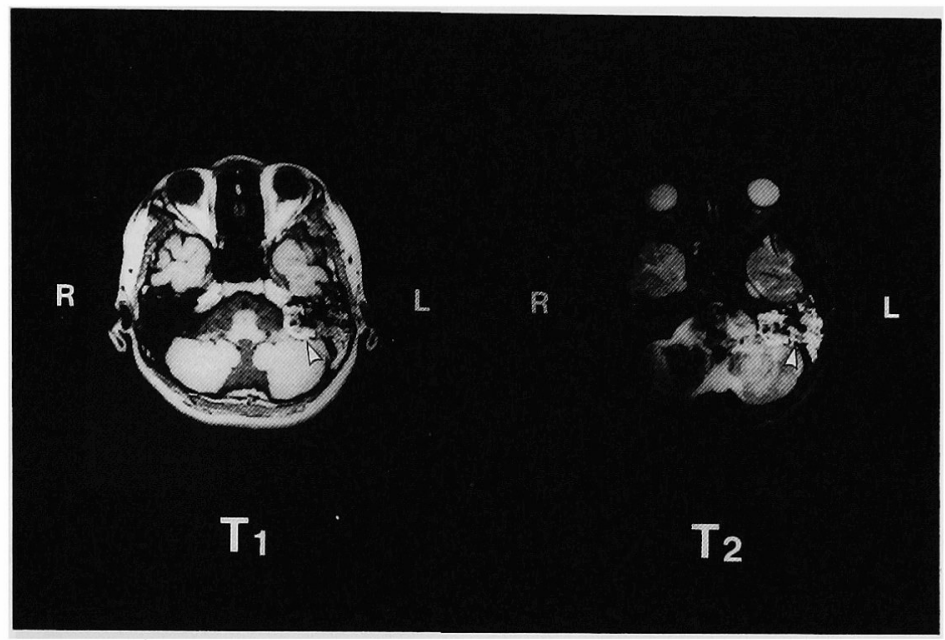

図 4 MRI（側頭骨水平断）

左は $T_{1}$ 強調像, 右は $T_{2}$ 強調像である. $T_{1}$ 強調像での等信号域は $T_{2}$ 強 調像で高信号域となっている.

表 1 血中カテコラミン測定

$$
\begin{array}{ccc}
\text { アドレナリン } & <0.01 \mathrm{ng} / \mathrm{ml}(<0.12) \\
\text { ノルアドレナリン } & 0.06 \mathrm{ng} / \mathrm{ml}(0.06-0.45) \\
\mathrm{VMA} & : & 3.0 \mathrm{ng} / \mathrm{ml}(3.3-9.9)
\end{array}
$$

表 2 尿中カテコラミン( 3 日間の平均値)

\begin{tabular}{ccc}
\hline アドレナリン: & $16.5 \mu \mathrm{g} /$ 日 $(3.0-15.0)$ \\
ノルアドレナリン & $115.7 \mu \mathrm{g} /$ 日 $(26.0-121.0)$ \\
ドー パ ミ ン & $1421.4 \mu \mathrm{g} /$ 日 $(190.0-740.0)$ \\
5-HIAA & $:$ & $5.2 \mathrm{mg} /$ 日 $(1.0-6.0)$ \\
VMA & $:$ & $2.7 \mathrm{mg} /$ 日 $(1.3-5.1)$ \\
HVA & $:$ & $4.6 \mathrm{mg} /$ 日 $(1.5-6.6)$ \\
\hline
\end{tabular}

表 3 選択的採取による血中カテコラミン

\begin{tabular}{c|r|c}
\hline & 左内頸静脈 & 大腿静脈 \\
\hline VMA & $1.7 \mathrm{ng} / \mathrm{ml}$ & $3.0 \mathrm{ng} / \mathrm{ml}(3.3-9.9)$ \\
5-HIAA & $11.3 \mathrm{ng} / \mathrm{ml}$ & $14.4 \mathrm{ng} / \mathrm{ml}(3.6-21.5)$ \\
\hline
\end{tabular}

\section{入院後経過}

Glomus jugulare tumor の可能性を第一に考え, 他 の側頭骨腫瑒である場合の対応も考虑して, 広範な temporal bone resection ができるように, 経中頭蓋法 に infratemporal fossa approach 加味した方法で 手術を行った.

左上頸部から耳介後部を通り, 頭頂部に至る皮切を 加えた. 次に軟骨部外耳道を完全に切断し, 皮弁を前
方へ剝離し煩骨弓を露出させた。これは，側頭骨内内 頸動脈を露出する場合を考えて，煩骨弓，下顎骨関節 突起を一時的に離断することにしたためである．側頭 骨を広範に剝離して,まず側頭開頭を行った。これは, 鏵体部を上方上り硬膜外で観察し, 硬膜内に腫湯進展 があれば，これに対する手術操作を容易にするためで ある.このために直径 $3 \mathrm{~cm}$ の bone flap を作って開頭 を行った。この際, 鍾体外面を硬膜下に観察したとこ ろ, その前面, 後面に腫湯増生などの異常所見は認め られなかった。次に乳様突起削開術により腫瘍に到達 した．乳突部を削開し，さらに中頭蓋窩をなす錘体前 面を外側より削開し，側頭開頭部と乳突削開部が連続 する単一の創腔になるよう手術を進めた，乳突部，錘 体部には, 海綿状に変性した骨病変がみられ, その間 に軟組織からなる易出血性の腫怚部分が見られた。こ の黄赤色の軟組織は何力所にも非連続的に局在する形 となっていた，また，この腫場性病変は顔面神経垂直 部では, その内側に骨破壊を伴った腫瘍塊として存在 した(図 7 ).鼓室内には異常所見はみられなかったが, 蝸牛, 半規管とも機能廃絶の状態であったので内耳開 放を行った。 下鼓室の下方を削開すると腫崵塊が現わ れ, これは内頸動脈, 内頸静脈の走行が推定される部 位へ増殖し, 前方へは蝸牛の前方まで増殖していた。 術中迅速生検の結果で, 確定診断はできなかったが, 悪性腫瘍が否定されたため, partial temporal bone resectionにとどめ, 顔面神経を膝神経節より茎乳突孔 まで露出させ； その周囲の腫瑒を可及的に除去した。 


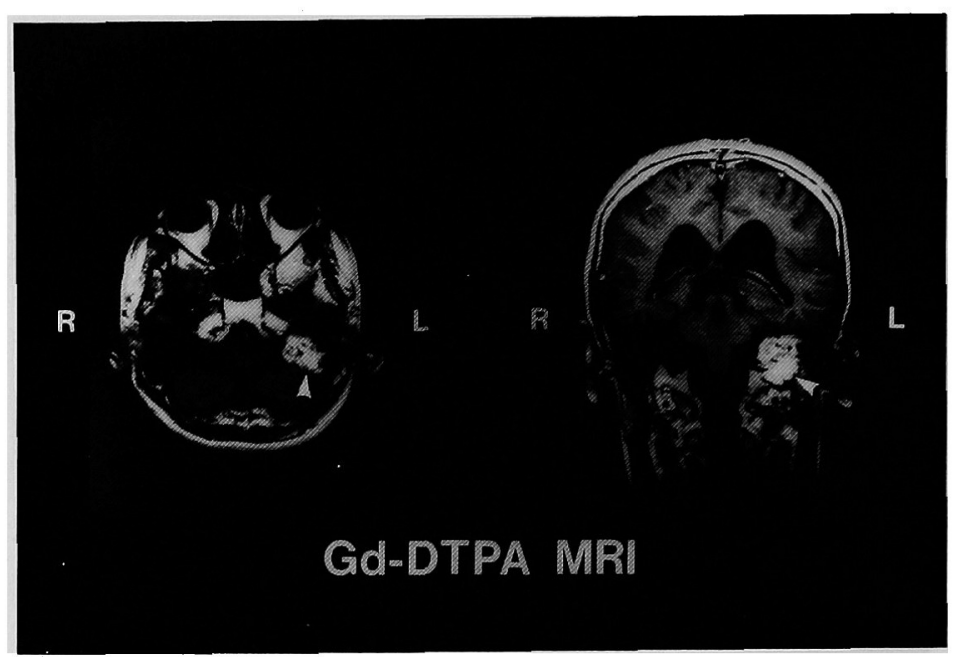

図 5 Gd-DTPA MRI（側頭骨水平断および冠状断）

図 4 の $\mathrm{T}_{2}$ 強調像での高信号域にほほ一致して, Gd-DTPAによる信号 の増強が認められる。

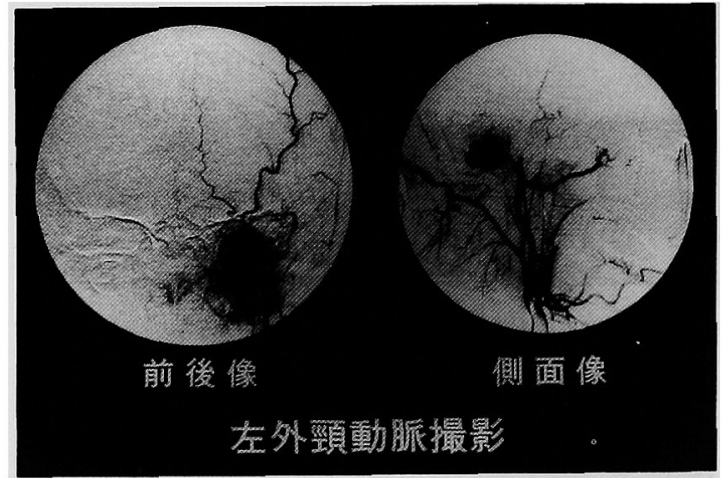

図 6 左頸動脈造影

左上行咽頭動脈が栄養動脈として示唆され た。

従って, 顔面神経の前方移動”) は行わなかった. $\mathrm{S}$ 状静 脈洞には腫湯の浸潤がみられなかったので，一部壁が 露出されたのみで, 静脈切除はなされなかった.

耳管鼓室口を bone wax を用いて塞いだ後, 創腔お よびその周囲の形成を行った。まず下顎骨関節突起は ミニプレートを用いて固定し，煩骨弓は前方をミニプ レートを用いて固定し，後方は free とした。側頭部の bone flap をもとに戻し,ナイロン系で固定した. 側頭 筋を前後に二分し, 後方のものを側頭骨の創腔を充填 するための rotation flap として用いた. 切断した外耳 道の皮膚切断端を縫合し，外耳道を閉鎖した。

術後 3 カ月の CT では, 明らかな腫瘍の再発像は認 められなかった (図 8 )。術直後より，顔面神経麻痹を

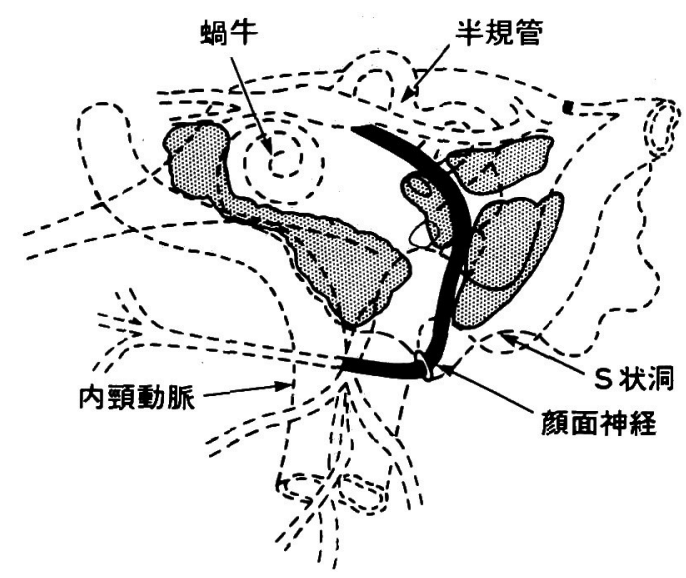

図 7 腫瘍存在部のシェーマ

点描の部分が腫瘍の存在した部である。黒 線部の顔面神経は露出した部分である。

きたしたが, 術後 3 カ月頃より回復がみられ, 現在(術 後32力月）はほほ問題なく回復している. 外耳道は閉 鎖されているが，整容上問題はない。 また，䫟関節に 対しても手術的侵襲が及んだが，顎関節の機能障害は みられていない。

病理 組 織

H.E. 染色では, 腫瘍はわずかな間質を伴いながら, 乳頭状に増殖し, 腫瘍細胞は類円形の比較的均一な核 を有し，異形成は少なく，核分裂像はほとんど認めら れない(図 9).グリメリウス染色では, 腫揚細胞には 


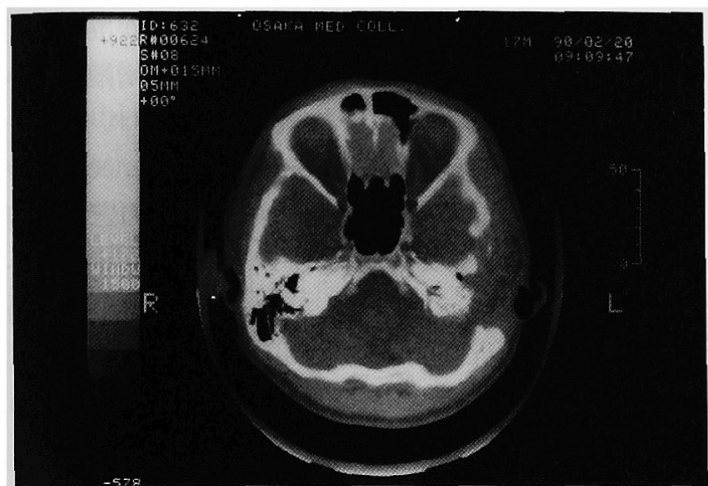

図 8 術後 3 力月の CT (側頭骨水平断) 左側は partial temporal bone resection に よる骨削開部である。腫沮の再発は認めら れない。
内分泌顆粒は認められなかった（図10)。また，S-100 蛋白免疫染色を行ったが腫瘍細胞は陰性であった。以 上の染色結果より, 本腫演は中耳粘膜原発の乳頭状腺 腫と診断された.

\section{考察}

中耳腺腫は, 症例数が少なく, 従ってその診断はし ばしば困難である.1976年に Hyamsと Michaels ${ }^{3)}$ が, 初めて20例におよぶ中耳原発の腺腫について病理 組織学的所見を明確に記載し, 中耳腺腫を一つの疾患 単位として確立した。それまでは，adenomatous tumor の多くを adenocarcinoma とする傾向があっ た。これは, 臨床的に, 術前に顔面神経麻痺や骨浸涺 をきたす腫瘍があったためと考えられている ${ }^{4) 51}$. 本邦

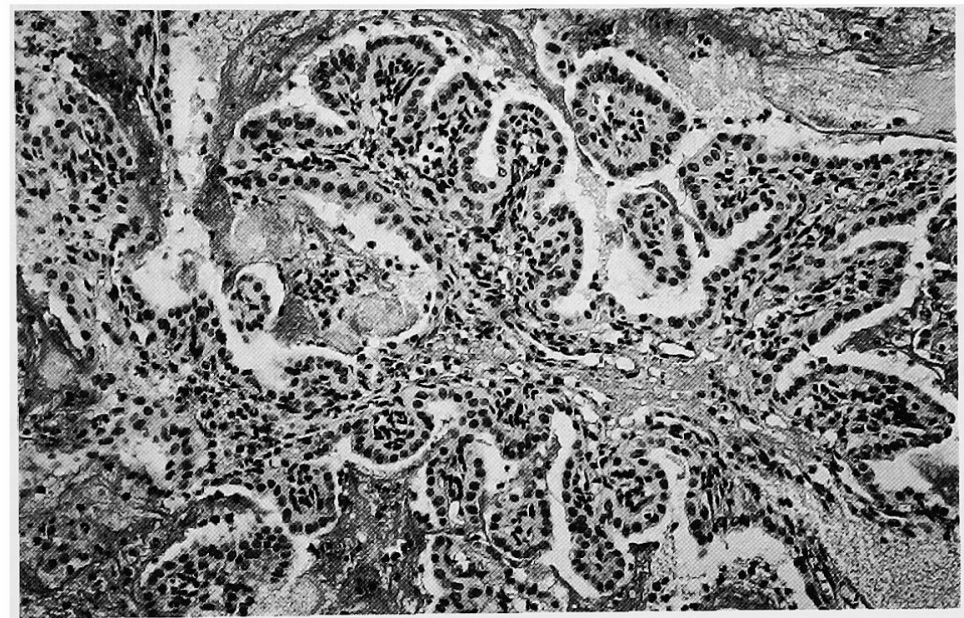

図 9 H.E. 染色写真 $(\times 200)$

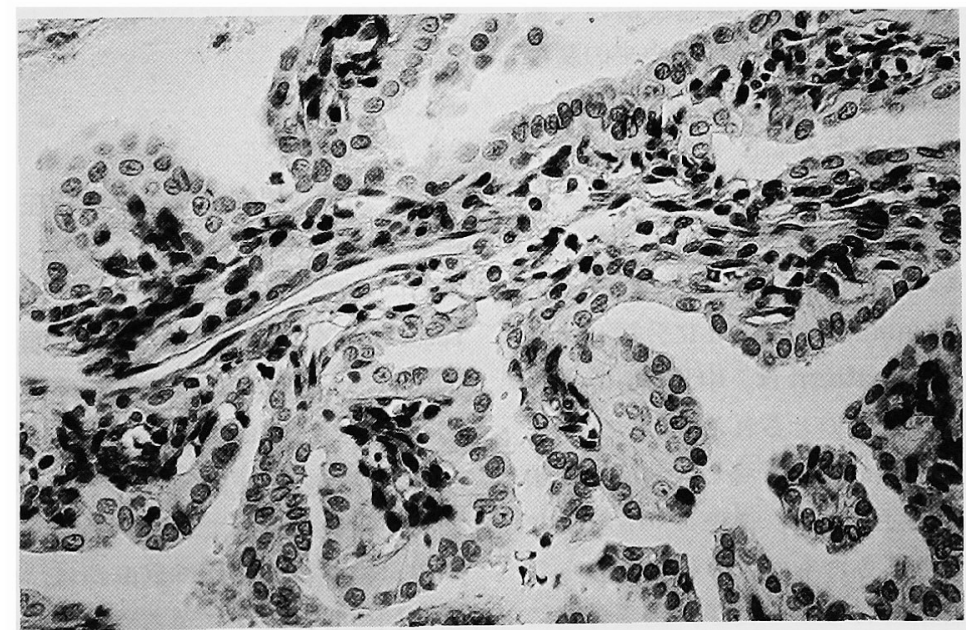

図10 グリメリウス染色写真 $(\times 400)$ 
では，中耳腺腫と確定されたのは過去に数例の報告が あるにすざない677?.

一般的に中耳腺腫は, 性差はなく, 年齢は平均 40 歳 で各年齢におこりうる ${ }^{5 / 6)}$. 症状は難聴，耳鳴，そして 時として顔面神経麻㾇，めまいなどである ${ }^{4) 6)}$. 術前診 断で中耳限局型は慢性中耳炎, 骨浸潤型は髄膜腫, 真 珠腫, Glomus jugulare tumor などと診断されること がある!! . 本症例は16歳男性で, 症状は左難聴, 左耳鳴 で発症した。術前診断は，CT で骨融解像，MRI で腫 瘍像を認めたため, Glomus jugulare tumor を第一に 考えた。

中耳原発の腫瘍としては, 腺腫, 腺癌, カルチノイ ド腫緜, Glomus jugulare tumor, 神経鞘腫, 耳㖔腺 腫などが挙げられる。これらの鑑別のため，近年では 通常の病理組織学的検索に加えて, 特殊染色, 兔疫組 織学的染色, 電子顕微鏡的検索を行うことも多くなっ てきている。

上記腫潢のうち, 腺腫とカルチノイド腫瘍, Glomus jugulare tumor, 神経鞘腫とは, 特殊染色, 免疫組織 学的染色を用いて鑑別可能となっている.すなわち, 腺腫では, 通常 neuroendocrine 産生がないため,グり メリウス染色で細胞質は染色されない( ${ }^{8) 99}$.また, NSE, S-100 蛋白による免疫組織学的染色でも, 腺腫は染色 されないとされている(18)10111).

一方, 中耳腺腫と耳垢腺腫との鑑別は, 光顕的に前 者は一層の細胞で囲まれた腺管であるのに対して, 後 者は二層の細胞で囲まれた腺管を有することが鑑別点 とされている5

今回著者らは，特殊染色としてグリメリウス染色， 免疫組織学的染色として S-100 蛋白染色を用いて鑑 別診断を行った. S-100 蛋白は神経鞘細胞由来の腫場 に陽性であり ${ }^{12)}$ ，また，腺腫で浩陰性である.腺腫の一 部は NSE 染色陽性のものもあること"1を考慮して今 回は S-100 蛋白染色を用いた。

一方, 近年, 病理組織学的に中耳腺腫に二種類の型 があると提唱されている. Beneckeらは, 腺腫を(1) mixed pattern と (2) papillary pattern に分類してい る4. 臨床的には, mixed pattern は, 中耳腔, 乳様蜂 巣に限局し骨浸潤はきたさないとされる。それに対し， papillary pattern は, 周井の骨に浸潤し，しばしば顔 面神経麻痺や頭蓋内合併症を伴い, 従来は low grade adenocarcinoma とされてきたものである゙．著者らの 今回の症例は顔面神経麻㾇はなかったが, 側頭骨内に 不規則に非連続的に進展していたこと, 術中, 肉眼的
に膜迷路に異常を認めなかったが内耳機能が廃絶して いたこと，また病理組織学的にも乳頭状に增殖してい たことなどから papillary pattern と考えられる。

治療は全例手術適応とされる Batsakis $^{5}$ は, 腫境の進展範囲に応じて次の三つの術 式が考慮されるとしている. (1) transtympanic excision or postauricular simple excision, (2) tympanomastoidectomy or radical mastoidectomy, （3） temporal bone resection. 本症例の場合, 前述の ように, 腫汮進展範囲と悪性の可能性を考慮したため, 経中頭蓋法に Fisch" ${ }^{2)}$ が考案した Infratemporal fossa approachを加味したapproachをとり, temporal bone resectionにも対応できる術式で臨んだ.しかし， 術中迅速生検で悪性が否定されたため, partial temporal bone resectionの術式を選択することにした. Jackson $^{13)}$ は, 中耳原発の腺腫 2 例を報告し,その中で 治療法のガイドラインを述べている。そこでは，診断 不確実な側頭骨腺腫を安易に悪性として拡大手術，放 射線治療などによって治療しようとする態度を批判 し,中耳腺腫という良性の腫瘍のあることを認識して, 臨床的所見をよく検討し，得られた永久標本について 十分な病理組織学的検索を行うことが重要であると強 調している. 従って, 本症例のごとく, 術中所見およ び迅速生検を考慮し, 術式を弾力的に選択することが 望ましいと考えられる。

術後経過について Benecke ら ${ }^{4)}$ 治, 本症に対して比 較的大きな手術を要した症例においても再発する例の あることを挙げ，10年以上の経過観察が必要であると 述べている．このような観点から，本症例は現在再発 の所見を示していないが, 今後十分な経過観察が必要 と考えられる.

\section{まとめ}

1） 16歳，男性で側頭骨に存在した中耳粘膜原発の 腺腫の非常にまれな 1 例を報告した。

2) 術式は内耳を含めた partial temporal bone resection を行い, 側頭骨内で顔面神経露出後, 腫瘍を 摘出した，創腔には側頭筋を前後に二分し，後方のも のを rotation flap として充填した。

3）腫渲の確定診断に,グリメリウス染色, S-100 蛋 白免疫染色は有用であった。

4）術直後の顔面神経麻痺は, 保存的治療でほほ正 常に回復し，現在に至るまで腫瘍の再発はみられてい ない. 


\section{参考文献}

1) Treitel $L$ : Ueber des carcinom des chres. Z Ohrenheilkd $33:$ 152-164, 1898.

2) Fisch U : Infratemporal fossa approach for glomus tumors of the temporal bone. Ann Otol Rhinol Laryngol 91 : 474-479, 1982.

3) Hyams VJ, Michaels I : Benign adenomatous neoplasm (adenoma) of the middle ear. Clin Otolaryngol 1: 17-26, 1976.

4) Benecke Jr JE, Noel FL, Carberry JN et al: Adenomatous tumors of the middle ear and mastoid. Am J Otol $11: 20-26,1990$.

5) Batsakis JG: Adenomatous tumors of the middle ear. Ann Otol Rhinol Laryngol 98: 749-752, 1989.

6) 山本悦生, 広野喜信, 大村正樹, 磯野道夫, 水上 千佳司：中耳腺腫症例。日耳鼻 93：2047-2051， 1990.

7)渡辺悟郎, 黑由一, 福永昇, 岡本途也, 小林 一女：中耳腺腫の一例. 臨床耳科 $16: 126,1989$.

8) McNutt MA, Bolen JW : Adenomatous tumor of the middle ear. An ultrastructual and immunocytochemical study. Am J Clin Pathol 84: 541-547, 1985.

9) Kodama H, Takezawa H, Suzuki T et al : Carcinoid tumor of the middle ear. J Laryngol Otol 103: 86 $-91,1989$.

10) Davies JE, Semeraro D, Knight LC et al : Middle ear neoplasms showing adenomatous and neuroendocrine components. J Laryngol Otol 103 : 404-407, 1989.

11) Wassef M, Kanavaros P, Polivka $M$ et al : Middle ear adenoma. A tumor displaying mucinous and neuroendocrine differentiation. Am J Surg Pathol 13: 838-847, 1989.

12) 中島 孝: 神経組織抗原の免疫組織化学. 腫湯を中心 に. 病理と臨床 6 臨時堌刊号：134-140, 1988.

13) Jackson CG, Glasscock ME : Primary adenoma of the middle ear. Am J Otol $2: 105-107,1980$.

本稿を終えるにあたり，本症例の治療に際してご協力い ただいた田嶋定夫先生 (大阪医科大学形成外科)，黒岩敏彦 先生, 山田恭造先生 (大阪医科大学脳神経外科) に深謝いた します。

(1993年3月 8 日受稿 1993 年 7 月29日受理)

別刷請求先 7569 高梘市大学町 $2-7$

大阪医科大学耳鼻咽喉科学教室 林 伊吹 


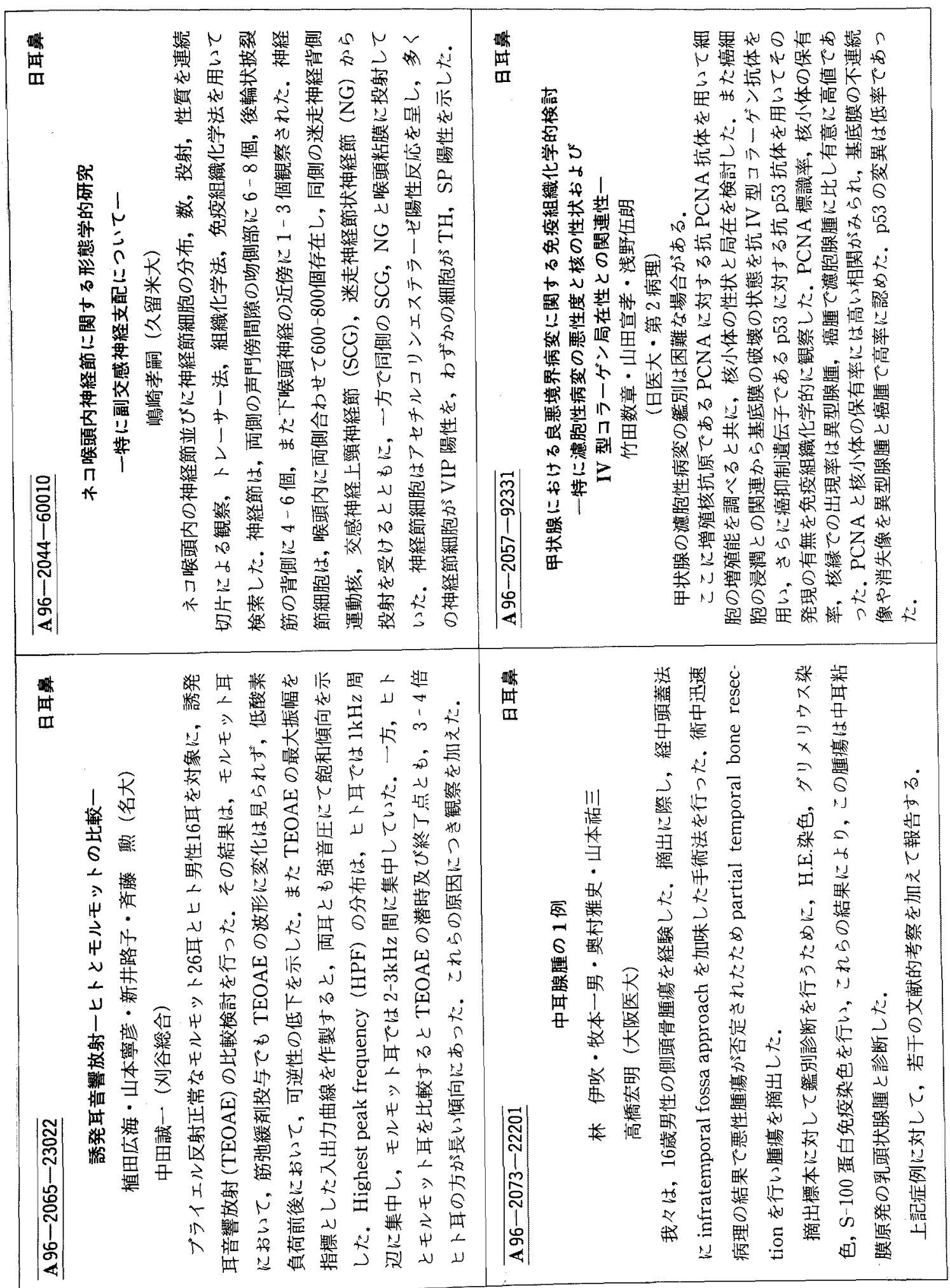

